Policy l.esfarch Working Paper 1254

What Are OECD Trade

Preferences Worth to Sub-Saharan Africa?

Alexander J. Yeats
The proposed Uruguay

Round reductions in most-

favored-nation tariffs will

cause some African exports to

be displaced by other

suppliers. Aggressive reform

of the African countries' own

trade regimes appears to be

the most effective way to

counter the effects of the

erosion of OECD preferences.

The World Bank

International Economics Department

International Trade Division

February 1994 


\section{Summary findings}

Some developing countries may experience important tracle losses if tariffs are liberalized on a general mostfavored-nation (MFN) basis. Sub-Saharan Africa appears to be especially vuluerable to this problem.

African countries reccive important Lomé Convention preferences in the European Economic Community (EEC), under which duty-free treatment, or tariffs below MFN and generalized system of preference (CSP) rates, are applied to their exports. Other OECD countries normally apply GSP duties, or even more advantageous "least developed" country preferences to African exports.

The proposed Uruguay Round reductions in MFN tariffs will erocie those tariff preference margins and cause some African exports co be displaced by other suppliers.

Yeats documents the importance to African countries of existing OECD preferences, particularly those of the EEC. More than 9.5 percent of all African-tariff-line products shipped to the EEC reccive duty-free treatment, while other exporters of the same products face tariffs as much as 20 percentage points higher.

Similar favorable terms of preferential access also exist in Japan and the united States, although the preference margins are smalle, than in the EEC.

Using a trade projection model developed by the
World Bank and UNCTAD, Yeats estimates that climinating EEC: Japanese, and U.S. MFN tariffs would cause African export losses of about $\$ 4$ billion (estimated present value). The countries that seem to be most vulnerable to these adverse trade effects are Côte d'Ivoire, Ethiopia, Kenya, Malawi, Senegal, Uganda, and Zimbabwe.

What about the possibility that the losses African countries could experience from erosion of tariff prefeiences could be offset by the liberalization of nontariff measures? Yeats discounts this likelihood.

In general, few important OECD nontariff measures are applied to African products - most African textile and clothing exports are sven excluded from Multifibre Arrangement restrictions. And those that are applied (such as eco-labeling or licensing requirements) do not restrict trade very much.

Yeats' observations accent the need for actions to ofíset the impact of Africa's loss of preferences as a result of the Uruguay Round. What offsetting actions are possible and appropriate? Aggressive reform of the African countries' own trade regimes appears to be the most effective way to counter the effects of the erosion of OECD preferences.

This paper - a product of the International Trade Division, Intirnational Economics Department - is part of a larger effort in the department to analyze and predict structural changes in trade and to identify factors affecting the exports of developing countries. Copies of the paper are available free from the World Bank, $1818 \mathrm{H}$ Street NW, Washington, DC 20433. Please contact Jean Jacotson, room S7-037, extension 33710 (27 pages). February 1994.

The Policy Research Working Paper Serip: disseminates the findings of work in progress to encourage the exchunge of ideas about development isues. An objective of the series is. , get the findings out quickly, even if the presentations are iess than fully polished. The papers carry the numes of the authors and should be used urul cited accordingly. The findings, interpretations, and conclusions are the authors' oum and should not be attributed to the World Bank, its Executive Baard of Directors, or any of its member countries. 


\section{WHAT ARE OECD TRADE PREFERENCES WORTH TO SUB-SAHARAN AFRICA?}

by,

Alexander J. Yeats

Principal Economist, International Trade Division

The World Bank, Washington D.C. 20433 


\title{
What Are OECD Trade Preferences Worth to Sub-Saharan Africa?
}

\author{
Alexander J. Yeats
}

\section{Introduction}

A problem which has complicated multilateral trade negotiations like GATT's Uruguay Round is that OECD countries have adopted important departures from the mostfavored-nation (MFN) principle in their trade regimes. Recently these departures have taken the form of regional trade preferences, such as the Canada-United States Free Trade Arrangement, NAFTA, the Australia-New Zealand Free Trade Arrangement, or European Community and EFTA preferences for Eastern Europe. ${ }^{1}$ Developing countries receive important trade preferences under the OECD countries' Generalized System of Preference (GSP) schemes, and through preferences extended under the EEC Lome Convention and the US Caribbean Basin Initiative (CBI). ${ }^{2}$

${ }^{1}$ Braga and Yeats (1992, Table 1) estimate that almost 50 percent of world trade in manufactures occurs under preferences. European trade accounts for almost two thirds of this total with the EEC and EFTA arrangements being of particular importance. Aside from the intra-trade of countries within these two groups, which is all duty free, a protocol allows for duty free trade in manufactures between EEC and EFTA. According to Braga-Yeats tabulations the European arrangements cover a trade value more than seven times greater than that of NAFTA intra-trade. See Appendix A in Schott (1989) for a listing of free trade arrangements that have been notified to the GATT.

${ }^{2}$ Several points should be noted concerning GSP preferences. First, some agricultural and manufactured products are exempted and developing countries' exports of these goods encounter MFN tariffs. Second, GSP treatment may be withdrawn from specific products once predetermined ceilings are reached. Third, several countries like Singapore, Hong Kong and Taiwan (China) have been "graduated" from GSP schemes and no longer receive their tariff preferences. Other developing country suppliers may also have GSP preferences withdrawn if they fail "competitive need" tests, i.e., they are judged able to compete successfully with other suppliers without preferences. Many GSP schemes extend even lower preferential tariffs than those receivud by other developing countries to the "least developed" countries. Least developed countries in Africa are: Benin, Botswana, Burkina Faso, Burundi, Cape Verde, Central African Republic, Chad, Comoros, Djibouti, Equaiorial Guinea, Ethiopia, Gambia, Guinea, Guinea-Bissau, Lesotho, Liberia, Madagascar, Malawi, Mali, Mauritania, Mozambique, Niger, Rwanda, Sao Tome and Principe, Sierra Leone, Somalia, Sudan, Togo, Uganda, Tanzania, Zaire and Zambia. 
Since the Uruguay Round will lower trade barriers on an MFN basis it poses a dilemma for preferrnce-receiving countries. Specifically, MFN tariff reductions will erode these countries' margins of preference and cause their competitive position to deteriorate vis-avis other suppliers. Trade losses will occur as some preference-receiving goods are displaced (diverted) by exports from other (non-preference receiving) countries. As a result, preferencereceiving countries could justifiably try to minimize reductions in MFN tariffs. ${ }^{3}$ Overall, the strategy which these countries might adopt vis-a-vis the multilateral trade negotiations could be determined by an assessment of whether the likely trade gains from lower MFN tariffs on their non-preference receiving goods would offset the expected losses from their preference-receiving exports.

This study examines the problem of preference erosion from the perspective of Sub-Saharan African countries. Sub-Saharan Africa (SSA) was selected for analysis due to the extensive multiple tariff preferences these countries receive in OECD markets (i.e JSP, Lomè Convention and, in many cases, least developed country preferences), and the fact that the region's export growth has been below that of most other countries (World Bank, 1992). Three separate issues are addressed. First, the relative importance of specific products and of

\footnotetext{
${ }^{3}$ For some products with non-zero preference duties it may be possible to reduce isth the MFN and preferential tariff so no reduction in the margin of preference occurs. However, the Uruguay Round is focussed on MFN tariffs and any compensating adjustments in preferential tariffs would have to be made at the discretion of the donor country. UNCTAD (1982) argues that the Tokyo Round resulted in major trade lesses for some developing countries due to the erosion of trade preferences and has expressed concerns that the Uruguay Round will have similar detrimental effects. It should be noted that sonie exporters such as the so called "least developed" countries often face zero OECD preferential duties, so these margins could not be adjusted to offset MFN tariff cuts. See footnote 2 for a list of least developed African countries.
} 
OECD markets for African exporters is assessed to determint where analysis of the Uruguay Round's effects should focus. Second, detailed information on trade barriers maintained by the World Bank and UNCTAD is employed to assess the importance of tariffs (and tariff गreferences) facing African countries in their key cxport markets. This section employs a World Bank trade projection model to quantify the effects of MFN tariff cuts on African exports. Third, the study employs an inventory of OECD countries' nontariff measures to assess the incidence of these rstrictions on African exports and the likely effects of their liberalization. The intention here is to determine whether or not liberalization of nontariff barriers could offset potential export losses African countries will experience due to erosion of tariff preferences.

\section{The Relative Importance of African Export Markets}

An important first question for any assessment of MFN tariff cuts relates to identification of the key markets for African exports since it is here that trade barrier liberalization will have its maximum impact. Table 1 provides relevant information by showing the value and share of individual African country exports destined for major groups of importing countries, i.e., " " developed countries, the EEC, North America, other Sub-Saharan countries, etc. ${ }^{4}$ The major point that emerges from these figures relates to the overall importance of

${ }^{4}$ The statistics in Table 1 are mainly for 1988 and are based on information reported by African countries to the United Nations. While similar tata for most other countries is one to two years out of date, African trade statistics are typically less current and much less reliable. Yeats (1990) analyzed the quality of African trade statistics and concluded that "the data cannot be relied on to indicate the level, composition, or even direction and trends in African countries' trade." For this reason Table 1 must be used with caution. The United Nations and IMF publish more recent total African trade statistics, but these data do not provide details on component products or the destination of exports. 


\begin{tabular}{|c|c|c|c|c|c|c|c|c|c|c|}
\hline \multirow[b]{3}{*}{ Exporting Country } & \multicolumn{10}{|c|}{ Share of total exports destined for (percentage) } \\
\hline & \multirow[b]{2}{*}{$\begin{array}{c}\text { World } \\
\text { (\$million) }\end{array}$} & \multirow[b]{2}{*}{$\begin{array}{l}\text { Developed } \\
\text { Countries }\end{array}$} & \multicolumn{3}{|c|}{ of which: } & \multirow[b]{2}{*}{$\begin{array}{l}\text { Eastem } \\
\text { Europe }\end{array}$} & \multirow[b]{2}{*}{$\begin{array}{c}\text { Socialist } \\
\text { Asia } \\
\end{array}$} & \multirow[b]{2}{*}{$\begin{array}{r}\text { Developing } \\
\text { Countries } \\
\end{array}$} & \multicolumn{2}{|c|}{ of which: } \\
\hline & & & $\operatorname{EEC}(12)$ & $\begin{array}{r}\text { North } \\
\text { America }\end{array}$ & Japan & & & & Africa & $\begin{array}{r}\text { South-East } \\
\text { Asia }\end{array}$ \\
\hline SUB-SAHARA AFRICA & $25,455.6$ & 77.7 & 47.4 & 24.4 & 2.8 & 2.4 & 0.6 & 17.2 & 9.8 & 0.3 \\
\hline Angola & $1,296.4$ & 81.5 & 34.5 & 45.0 & - & 0.3 & - & 18.0 & 1.8 & 0.6 \\
\hline Cameroon & 924.0 & 67.5 & 60.3 & 5.4 & 1.2 & 4.1 & - & 28.5 & 22.3 & 2.0 \\
\hline Central African Rep. & 135.0 & 69.5 & 65.3 & 2.3 & 0.6 & - & 1.5 & 23.9 & 9.9 & 10.6 \\
\hline Chad & 141.0 & 32.2 & 31.3 & - & - & - & - & 67.8 & 60.6 & 1.4 \\
\hline Congo & 776.9 & 65.6 & 31.5 & 33.3 & 0.5 & 0.7 & - & 33.6 & 1.4 & 1.4 \\
\hline Cote d'Ivoire & $2,906.0$ & 64.4 & 54.4 & 8.6 & 0.7 & 5.3 & 0.1 & 25.0 & 22.8 & 1.7 \\
\hline Ethiopia & 358.0 & 82.3 & 59.3 & 13.6 & 8.0 & 6.9 & 0.2 & 10.5 & 3.2 & 0.4 \\
\hline Gabon & $1,429.0$ & 68.2 & 50.5 & 12.7 & 1.7 & 1.9 & 0.5 & 25.6 & 6.4 & 8.6 \\
\hline Ghana & $1,014.0$ & 79.9 & 40.8 & 24.6 & 9.0 & 11.6 & 0.1 & 8.4 & 1.6 & 4.3 \\
\hline Kenya & 961.0 & 64.1 & 47.0 & 10.6 & 0.6 & 0.1 & 0.4 & 31.4 & 22.7 & 5.4 \\
\hline Liberia & 404.4 & 96.9 & 77.9 & 17.9 & 0.9 & - & - & 3.1 & 2.3 & 0.2 \\
\hline Madagascar & 316.6 & 84.9 & 58.2 & 15.4 & 10.9 & 3.6 & 1.9 & 8.8 & 3.7 & 5.0 \\
\hline Malawi & 286.9 & 78.3 & 40.3 & 13.8 & 8.7 & - & - & 18.8 & 16.1 & 1.3 \\
\hline Mali & 192.0 & 34.7 & 28.0 & 3.3 & 2.2 & 28.5 & 0.2 & 34.0 & 27.8 & 6.1 \\
\hline Mauritania & 427.8 & 72.6 & 44.2 & 1.4 & 27.0 & 15.0 & 0.3 & 10.1 & 9.6 & 0.5 \\
\hline Mauritius & 997.5 & 93.2 & 76.5 & 15.0 & 0.2 & 0.4 & - & 5.1 & 3.7 & 1.3 \\
\hline Niger & 91.2 & 70.0 & 66.6 & 2.6 & 0.7 & - & - & 29.9 & 29.9 & - \\
\hline Nigeria & $7,382.6$ & 91.2 & 41.5 & 49.1 & 0.1 & - & - & 8.8 & 6.1 & 0.1 \\
\hline Reunion & 160.8 & 89.6 & 85.8 & 0.2 & 2.7 & - & - & 10.4 & 10.2 & - \\
\hline Senegal & 606.3 & 47.1 & 45.1 & 0.4 & 1.2 & - & 0.1 & 29.8 & 18.9 & 5.8 \\
\hline Sierra Leone & 148.0 & 74.7 & 65.0 & 9.3 & - & 0.7 & - & 9.0 & 2.t: & 0.3 \\
\hline Sudan & 509.1 & 39.5 & 28.6 & 3.7 & 6.1 & 8.6 & 0.5 & 51.4 & 8.6 & 21.0 \\
\hline Swaziland & na & na & na & $\mathbf{m a}$ & na & $\mathbf{n a}$ & na & ma & na & na \\
\hline Togo & 245.1 & 43.7 & 12.6 & 0.9 & 0.9 & 6.4 & 0.3 & 31.0 & 14.0 & 13.7 \\
\hline Uganda & 436.0 & 85.2 & 51.8 & 28.0 & 3.6 & 0.8 & - & 13.9 & 10.6 & 1.4 \\
\hline United Rep. Tanzania & 346.0 & 79.0 & 64.1 & 3.3 & 5.3 & 0.7 & 1.8 & 18.2 & 4.2 & 11.5 \\
\hline
\end{tabular}

Source: UNCTAD, Handbook of International Trade and Develoyment Statistics, (Geneva: UNCTAD) and UN COMTRADE records. Statistics for Guinea were not available and exports from Botswana and Swaziland are recorded in totals for the South African Customs Union. Several smailer countries like Eambia were excluded from the above due to the low value of their exports. The percentages may not sum to 100 since about 3 percent of Sub-Sahara Africa's exports are not allocated by destination. 
developed countries as markets for African exports and, within the developed country group, the singular importance of the EEC.

For Sub-Saharan Africa as a whole about 78 percent of all exports go to developed countries and this share equals 90 percent or more for Liberia, Mauritius and Nigeria. Ruughly 6) percent of all African exports to developed countries are destined for the EEC (these shipments account for 47 percent of African exports). North America accounts for about onehalf the value of EEC trade. Japan is marginal, receiving less than 3 percent of African exporis. One-half (14 of 28) of the African countries have over 50 percent of their exports destined for the EEC -- the share exceeds 75 percent in the case of Liberia, Mauritius and Reunion. In short, Table 1 clearly indicates that Uruguay Round trade liheralization measures adopted by the EEC will be of key importance for African countries, but developments in the North American market will also have a major impact.

Having established the importance of OECD markets (particularly the EEC) for Africa, a second related consideration for assessing the influence of MFN tariff cuts concerns identification of the major African export products. Table 2 provides an indication by tabulating the value and share of the 30 largest non-oil three-digit SITC products exported by African countries to OECD markets in 1970, 1980, and 1990.5 These export items account for approximately $\$ 16.5$ billion in trade or 92 percent of total non-oil African exports tn OECD markets. In addition, the table also provides similar information for five broad classes of

'Several earlier years of data have been included to help assess changes in the relative importance of African exports. Crude petroleum (SITC 331) dominates African trade, with this single three-digit product accounting for over 50 percent of total exports. Petroleum was excluded from Table 2 in order to better indicate the relative importance of other products to African countries that are not energy exporters. Also, crude petroleum generally does not face OECD trade barriers so it would not be directly affected by the Uruguay Round. 
goods, namely: foodstuffs; agricuitural raw materials; ores, minerals and nonferrous metals; mineral fuils; and manufactured goods.

One major poirt that emerges from Table 2 concerns the importance of raw materials and non-temperate zone foodstuffs in African exports and the unimportance of manufactured goods. This prnduct orientation has impcrtant implications since most studies (see Laird and Yeats, 1987, for example) skow that OECD tariffs and other trade harriers are relatively high for manufactures but are generally zero or relatively low for raw material products of the sort Africa exports. Non-fur clothing (SITC 841) normally faces inghly 2.strictive barriers in OECD markets and cor.stitutes a large share of mány developing countries' exports, but these products only account for abov: 4 percent of total African non-nil exports which mostly originate in Mauritius (this country accounts for about 90 percent of all African clothing exports to the OECD). ${ }^{6}$ Sugar and honey (SITC 061) exports face restrictive trade barriers in OECD markets (including strict quotas and variable import levies), as do exports of ferrous metals and fish: but for the most part the products in Table 2 generally encounter lower

\footnotetext{
'The statistics on "manufactures" exports in Table 2 may misrepresent the importance of these items in African exports due to anomalies in two product groups. Pearls and precious stones (SITC 667) account for about 10 percent of African non-oil exports, but there is disagreement as to whether these items are "manutactures" (as they are recorded in Table 2). The problem is that the SITC does not diffe:entiate between cut and polished gems (which could be considered a manufactured good) and raw unprocessed stones which are a questionable manufacture. Mainly the latter are mainly exported from Africa, while polished gems typically are exported from more industrialized countries (like Israel). Second, ships and boats (SITC 735) account for about 6 percent of African exports, but these transactions largely reflect transfers under "flags of convenience" and not true manufacturing activity. Convention normally defines manufactured goods as all items classified in SITC groups 6 through 8 less $\leqslant$, although it is recognized that there are problems with this procedure (See Yeats 1992).
} 
Table 2. The Thirty Largest Non-Energy Three-Digit SITC Products Exported by Sub-Saharan Africa to OECD Markets in 1970 , 1980 and 1990.

\begin{tabular}{|c|c|c|c|c|c|c|}
\hline \multirow[b]{2}{*}{ Product Group (SITC) } & \multicolumn{3}{|c|}{ Share of Total Exports (\%) } & \multicolumn{3}{|c|}{ Value of Exports (Smillion) } \\
\hline & 1970 & 1980 & 1990 & 1970 & 1980 & 1990 \\
\hline Pearls and preciuus stones (667) & 1.9 & 3.0 & 9.6 & 112 & 529 & 1,739 \\
\hline Copper $(682)$ & 24.8 & 10.8 & 9.4 & 1,496 & 1,904 & 1,703 \\
\hline Cocoa $(072)$ & 10.0 & 12.2 & 8.6 & 606 & 2,144 & 1.572 \\
\hline Coffee $(071)$ & 13.6 & 16.5 & 7.9 & 819 & 2,903 & 1,433 \\
\hline Ships and boats (735) & 0.2 & 1.1 & 6.0 & 13 & 185 & 1,095 \\
\hline Wood in the rough $(242)$ & 5.2 & 6.9 & 4.9 & 315 & 1,213 & 896 \\
\hline Ores of non-ferrous metals (283) & 2.5 & 3.4 & 4.6 & 149 & 599 & 836 \\
\hline Fresh fish (031) & 0.5 & 1.1 & 4.3 & 30 & .93 & 785 \\
\hline Clothing not of fur (841) & -- & 0.6 & 4.0 & - & 102 & 720 \\
\hline Cotton (263) & 4.1 & 2.7 & 3.2 & 250 & 466 & 574 \\
\hline Sugar and honey (061) & 1.8 & 3.4 & 2.9 & 106 & 595 & 535 \\
\hline Wood shaped (243) & 1.0 & 1.3 & 2.9 & 02 & 238 & 525 \\
\hline Unmanufactured tobacco (121) & 0.8 & 1.4 & 2.4 & 48 & 254 & 448 \\
\hline Iron ore and concentrates (281) & 6.8 & 3.6 & 2.4 & 414 & 636 & 429 \\
\hline Fresh fruit and nuts (051) & 1.3 & 1.7 & 2.1 & 80 & 291 & 392 \\
\hline Aluminum (684) & 1.2 & 1.6 & 20 & 75 & 285 & 356 \\
\hline Radioactive materials (515) & 0.0 & 3.1 & 1.5 & $\mathbf{0}$ & 549 & 280 \\
\hline Tea and mate (074) & 1.5 & 1.5 & 1.5 & 92 & 266 & 278 \\
\hline Crude rubber (231) & 1.4 & 1.1 & 1.2 & 83 & 203 & 227 \\
\hline Crude vegetable materials, nes (292) & 0.9 & 0.9 & 1.2 & 52 & 163 & 220 \\
\hline Fish in airtight containers (032) & 0.2 & 0.6 & 1.1 & 12 & 102 & 200 \\
\hline Leather $(611)$ & 0.1 & 0.4 & 1.1 & 8 & 65 & 191 \\
\hline Pig iron (671) & 0.0 & 0.7 & 0.9 & 3 & 122 & 163 \\
\hline Plywood and veneers (631) & $0 . j$ & 0.7 & 0.9 & 31 & 126 & 163 \\
\hline Misc. non-ferrous metals (689) & 1.7 & 1.9 & 0.9 & 106 & 329 & 158 \\
\hline Special transactions (931) & 0.2 & 4.9 & C.8 & 10 & 868 & 150 \\
\hline Fixed regetable oils (421) & 1.6 & 0.7 & 0.8 & 98 & 117 & 140 \\
\hline Hides and skins (211) & 0.9 & 0.8 & 0.8 & 53 & 147 & 140 \\
\hline Nickel (683) & - & 0.3 & 0.7 & 2 & 44 & 121 \\
\hline Crude fertilizers (271) & 0.7 & 1.2 & 0.7 & 42 & 215 & 121 \\
\hline MANUFACTURES ( 5 to 8 less 68 ) & 3.8 & 5.0 & 13.4 & 265 & 2,205 & 5,087 \\
\hline FOODS $(0+1+22+4)$ & 36.7 & 17.4 & 16.7 & 2,494 & 7,729 & 6,390 \\
\hline AGRICULTURAL MATERIALS (2-22-27-28; & 12.9 & 5.7 & 6.9 & 877 & 2,529 & 2,619 \\
\hline ORES AND NONFERROUS METAL $(27+28+68)$ & 35.1 & 9.8 & 10.5 & 2,391 & 4,376 & 3,960 \\
\hline FUELS (3) & 11.1 & 60.1 & 51.9 & 759 & $2-705$ & 19.656 \\
\hline
\end{tabular}

Source: United Nations COMTRADE records. Import statistics as reported by OECD Countries to the United Nations. 
than average trade restrictions. ${ }^{7}$ This treatment should, in general, mitigate the impact of trade preference erosion on African exports.

\section{Tariff Protection Against African Exports}

The previous analysis showed Sub-Saharan exporters are primarily lependant on developed counuries for export mirkets and, within this group, the EEC is of special significance. Analysis of the terms of access that African countries have in the EEC is of key importance in any assessment of the impact of he Uruguay Round or general MFN tariff cuts. Table 3 summarizes the current profile of EEC. tariffs facing African sountries. These data attest to the importance of European preferences for African expcrts, and the adverse trade corsequences that could result if these preferences were eroded. For comparison, the table contrasts the African countries' situation with that of two more industrialized exporters, namely, Republic of Korea and Taiwan (China).

The key points evident from Table 3 relate to the high concentration of most African countries' exports in a very small number of tariff lines and the importance of existing trade preferences for these items. As an i!lustration, Table 3 shows Angola exported 134 taiff line products to the EEC (see the right most column -- the EEC customs schedule distinguishes

\footnotetext{
'For many of the raw material products in Table 2, trade barricrs increase or "escalate" with further processing. As an example, raw cotton (SITC 263) is generally freely traded, but more restrictive barriers are encountered after the item is processed into yarn, textiles, or clothing see Yeats 1987 for an analysis of the effects of suc ade barrier escalation on the exports of developing countries). Uruguay Round MFN tariff cuts may reduce important preference margins for some fledgling $A$ frican processing industries that have not yet achieved sufficient size to be included in Table 2 . Reductions in tariff preferences for these items may remove an important incentive to the further development of African processing industries.
} 
betwen 9,506 individual tariff lines) and that 25 of these items faced a zero MFN tariff. However, on 106 line items Angola received a zero preferenc; rate (second column from the left) with the result that 131 or 98 fercent of Angola's exports enter the EEC free of duty. In only two tariff lines (involving $\$ 10,000$ in total exports of fi esh grapes and strawberries) did Angcla not receive preferences and, as a result, paid the full MFN tariff. In short, Angola could experience trade gains from MFN tariff cuts on these two products and experience export losses on 131 tariff line items.

The data for other African exporiers reveal a situation similar to what for Angola. Preferences result in at least 97 percent of each African country's exports intering the Community free of duty, and in two cases (Congo and Guinea) no duties are paid on any line item. Table 3 also shows how markedly the profile of protection against African countries' exports differs from that of Republic of Korea and Taiwan (China). Onyy four percent of the latter's exoorts (less than 200 tariff line items out of a total of over 4,000 ) have EEC duty free access -- not due to preferences but because of a zero MFN rate. These comparisons underscore the differences in strategies regarding tariffs in the Uruguay Round. The Asian NiCs would clearly have a major interest in broad-based MFN tariff cuts, while African countries would want to limit MFN duty reductions to preserve their preferences.

\footnotetext{
${ }^{8}$ The picture is complicated somewhat by quotas or ceilings on some products receiving preferences. After these predetermined ceilings are exceeded further imports are taxed at the prevailing MFN rate. Comprehensive tariff line level information on how often these ceilings have been hit is not available, but aggregate statistics of preference utilization ratios provided by the EEC suggest that African countries' exports generally do not exceed ceilings.
} 
Table 3. Sub-Saharan Export Products Facing MFN or Preferential Duties in the European Community (No. of tariff line items).

\begin{tabular}{|c|c|c|c|c|c|c|c|}
\hline Exporting Country & $\begin{array}{l}\text { Tariff Lines } \\
\text { Facing a } \\
\text { Zero MFN Duty }\end{array}$ & $\begin{array}{c}\text { Zero } \\
\text { Preference } \\
\text { ¿ate Lines }\end{array}$ & $\begin{array}{c}\text { Total Lines } \\
\text { with Zero } \\
\text { Duties }^{1}\end{array}$ & $\begin{array}{l}\text { Non-Zero } \\
\text { Preference } \\
\text { Rate Lines }\end{array}$ & $\begin{array}{c}\text { Zero Duty } \\
\text { or Preference } \\
\text { Rate Lines' }\end{array}$ & $\begin{array}{l}\text { Non-Zero } \\
\text { MFN Duty } \\
\text { Lines }\end{array}$ & $\begin{array}{l}\text { Total } \\
\text { Tariff Lines } \\
\text { Exported }\end{array}$ \\
\hline Angola & 25 & 106 & 131 (98) & 1 & $132(98)$ & 2 & 134 \\
\hline Botswana & 33 & 94 & $127(99)$ & $\mathbf{0}$ & $127(99)$ & 1 & 128 \\
\hline Cameroon & 95 & 411 & $506(98)$ & 4 & $510(99)$ & 4 & 514 \\
\hline Central African Republic & 41 & 83 & $124(98)$ & 0 & $124(98)$ & 3 & 127 \\
\hline Chad & 21 & 51 & $72(97)$ & 1 & $73(99)$ & 1 & 74 \\
\hline Congo & 57 & 173 & $230(100)$ & $\mathbf{0}$ & $230(100)$ & $\mathbf{0}$ & 230 \\
\hline Cote d'lvoire & 121 & 595 & $716(97)$ & 6 & $722(98)$ & 14 & 736 \\
\hline Ethiopia & 67 & 111 & $178(98)$ & 1 & $179(99)$ & 2 & 181 \\
\hline Gabon & 55 & 261 & $316(100)$ & $\mathbf{0}$ & $316(99)$ & 1 & 317 \\
\hline Ghana & 63 & 250 & $313(99)$ & 2 & $315 \quad(99)$ & 2 & 317 \\
\hline Guinea & 50 & 109 & $159(100)$ & 0 & $157(100)$ & 0 & 159 \\
\hline Kenya & 108 & 438 & $546(98)$ & 4 & $550(98)$ & 10 & 560 \\
\hline Liberia & 57 & 84 & $141(96)$ & 1 & $142(97)$ & 5 & 147 \\
\hline Madagascar & 63 & 278 & $341(97)$ & 2 & 343 (98) & 8 & 351 \\
\hline Malawi & 28 & 140 & $168(98)$ & 2 & $170(99)$ & 1 & 171 \\
\hline Mali & 34 & 146 & $180(99)$ & 1 & $181(99)$ & 1 & 182 \\
\hline Mauritania & 18 & 125 & $143(99)$ & 0 & $143(99)$ & 4 & 144 \\
\hline Mauritius & 46 & 588 & 634 (99) & 2 & $636(99)$ & 6 & 642 \\
\hline Niger & 29 & 151 & $180(99)$ & 1 & $181(99)$ & 1 & 182 \\
\hline Nigeria & 127 & 392 & 519 (99) & 3 & $52 i(99)$ & 4 & 525 \\
\hline Senegal & 90 & 375 & 465 (98) & 4 & $469(99)$ & 6 & 475 \\
\hline Sierra Leone & 30 & 78 & $108(98)$ & 0 & $108(98)$ & 2 & 110 \\
\hline Sudan & 55 & 84 & 139 (99) & 1 & $140(99)$ & 1 & 141 \\
\hline Swaziland & 20 & 118 & $138(98)$ & 5 & $143(96)$ & 6 & 149 \\
\hline Togo & 48 & 170 & $218(96)$ & 2 & $220(97)$ & 6 & 226 \\
\hline Uganda & 25 & 60 & 85 (97) & $\mathbf{0}$ & $85(97)$ & 3 & 88 \\
\hline United Republic Tanzania & 79 & 219 & $298(99)$ & 1 & $299(99)$ & 2 & 301 \\
\hline Zaire & 97 & 217 & $314(98)$ & 0 & $314(98)$ & 7 & 321 \\
\hline Zambia & 48 & 125 & $173(93)$ & 8 & $181(97)$ & 5 & 186 \\
\hline Zimbabwe & 91 & 451 & $542(97)$ & 8 & 550 (99) & 6 & 556 \\
\hline $\begin{array}{l}\text { MEMO ITEM } \\
\text { Taiwan, China }\end{array}$ & 192 & 0 & 192 (4) & 0 & 192 (4) & $\begin{array}{l}4,080 \\
350\end{array}$ & $\begin{array}{l}4,272 \\
3,503\end{array}$ \\
\hline Republic of Korea & 153 & 0 & $153 \quad(4)$ & 0 & $153 \quad(4)$ & 3,350 & 3,503 \\
\hline
\end{tabular}

${ }^{1}$ Figures in parentheses show the percentage of all tariff lines covered. The EEC customs schedule differentiates between some 9,506 line item products.

Source: World Bank-UNCTAD SMART Data Base. 
Table 4 extends the foregoing analysis by examining the average preference margins current EEC tariffs provide African countries over other exporters and also gives similar information for the United States and Japan. The table shows the average nominal duty African countries paid on exports to each of these three markets and also indicates their average margin of preference -- a negative figure indicates the number of percentage points the African duty was below the average tariff facing other countries. For example, on its exports to the EEC Angola faced tariffs that averaged three-tenths of one percent, a rate 3.2 percentage points below the average duty facing other exporters of the same products. ${ }^{9}$ Similar statistics for Taiwan (China) and the Republic of Korea have again been included to contrast the African situation with that of more "industrialized" countries.

In the EEC, the average tariff facing African exporters typically ranges from zero to three-tenths of a percent with Uganda recording a high of 0.6 percent -- due mostly to a tariff of 18 percent on its exports of fresh grapes. The preference margins these tariffs provide African countries are typically in the two to four percentage point range and reach a high of 4.9 points for Swaziland. ${ }^{10}$ Although the margins vary, every one of the 30 African countries

\footnotetext{
${ }^{9}$ The duties shown in Table 4 are the unwe.ghted averages of tariffs applied to the African country's exports and the unweighted average paid by competitors. The tariff facing "other" exporters is the unweighted average of the MFN, GSP, Least Developed, ACP, or regional preference tariff applied to imports from all other supfliers of the same goods. Some industrial and advanced developing countries may face duties that are considerably higher than suggested by these African preference margins if there are significant imports from other Sub-Saharan countries, or if other preferences (GSP, EFTA-EEC, Least Developed, regional arrangements, etc.) cover a high share of trade and these rates are considerably below MFN duties.

${ }^{10}$ Swaziland exports mandarin and other oranges to the EEC and pays a full MFN duty of 4 percent on these shipments -- as it does on exports of a several fresh agricultural products including asparagus, lemons and other citrus. Outside the agricultural sector, Swaziland faces a MFN tariff of 8.5 percent on coal exports to the Community of about $\$ 1.6$ million.
} 
Table 4. The Incidence of OECD Tariffs on Sub-Saharan Countries' Non-Oil Exports (all figures in percent).

\begin{tabular}{|c|c|c|c|c|c|c|c|c|}
\hline \multirow[b]{2}{*}{ Exporting Country } & \multicolumn{2}{|c|}{ OECD Average } & \multicolumn{2}{|c|}{ European Community } & \multicolumn{2}{|c|}{ Japan } & \multicolumn{2}{|c|}{ United States } \\
\hline & $\begin{array}{c}\text { African } \\
\text { Tariff }\end{array}$ & $\begin{array}{c}\text { Preference } \\
\text { Margin' }\end{array}$ & $\begin{array}{c}\text { African } \\
\text { Tariff }\end{array}$ & $\begin{array}{c}\text { Preference } \\
\text { Margin' }\end{array}$ & $\begin{array}{c}\text { African } \\
\text { Tariff }\end{array}$ & $\begin{array}{c}\text { Preference } \\
\text { Margin' }\end{array}$ & $\begin{array}{c}\text { African } \\
\text { Tariff }\end{array}$ & $\begin{array}{c}\text { Preference } \\
\text { Margin }\end{array}$ \\
\hline Angola & 0.2 & -1.5 & 0.3 & -3.2 & 1.8 & 0.0 & 0.1 & -0.4 \\
\hline Botswana & 0.3 & -2.8 & 0.1 & -2.9 & 0.0 & -2.1 & 3.5 & -1.1 \\
\hline Cameroon & 0.4 & -2.5 & 0.1 & -2.8 & 0.0 & 0.0 & 2.1 & -1.1 \\
\hline Central African Republic & 0.2 & -2.2 & 0.2 & -2.3 & 0.0 & 0.0 & 0.0 & -1.1 \\
\hline Chad & 0.4 & -2.7 & 0.2 & -2.9 & 2.5 & 0.0 & 1.6 & 0.0 \\
\hline Congo & 0.1 & -1.4 & 0.0 & -2.2 & 0.0 & 0.0 & 0.3 & -0.6 \\
\hline Cote d'Ivoire & 0.7 & -3.1 & 0.3 & -3.3 & 1.2 & -0.5 & 3.3 & -2.0 \\
\hline Ethiopia & 0.7 & -1.3 & 0.1 & -1.9 & 1.5 & -1.3 & 2.0 & 0.4 \\
\hline Gabon & 0.6 & -2.0 & 0.0 & -2.7 & 0.0 & 0.0 & 2.9 & 0.7 \\
\hline Ghana & 1.0 & -2.2 & 0.1 & -3.1 & 2.3 & 0.0 & 2.6 & -0.9 \\
\hline Guinea & 0.6 & -2.3 & 0.0 & -2.9 & 1.8 & -1.9 & 1.9 & -1.0 \\
\hline Kenya & 0.5 & -3.3 & 0.2 & -3.5 & 2.4 & -1.1 & 3.1 & -2.3 \\
\hline Liberia & 0.6 & -1.7 & 0.3 & -1.9 & 0.0 & -0.3 & 2.5 & -1.1 \\
\hline Madagascar & 0.5 & -2.0 & 0.4 & -2.7 & 0.8 & -0.2 & 0.8 & -1.0 \\
\hline Malawi & 1.1 & -2.4 & 0.1 & -3.5 & 0.0 & -0.1 & 5.4 & -0.6 \\
\hline Mali & 0.4 & -3.4 & 0.2 & -3.5 & 0.0 & -1.6 & 3.1 & -2.2 \\
\hline Mauritania & 1.7 & -2.3 & 0.2 & -3.9 & 3.6 & -0.4 & 1.2 & -1.6 \\
\hline Mauritius & 1.3 & -3.1 & 0.2 & -3.4 & 4.8 & -1.1 & 6.4 & -1.8 \\
\hline Niger & 0.1 & -3.0 & 0.0 & -3.0 & 0.0 & 0.0 & 3.3 & -1.6 \\
\hline Nigeria & 2.7 & -0.9 & 0.1 & -2.6 & 3.7 & -0.8 & 5.2 & 0.7 \\
\hline Senegal & 0.5 & -3.3 & 0.3 & -3.5 & 3.6 & 0.1 & 4.9 & -1.2 \\
\hline Sierra Leone & 0.5 & -3.1 & 0.0 & -4.0 & 2.6 & -0.7 & 2.3 & -0.2 \\
\hline Sudan & 0.1 & -1.5 & 0.1 & -1.9 & 0.0 & 0.0 & 0.7 & -1.0 \\
\hline Swaziland & 0.8 & -4.4 & 0.5 & -4.9 & 6.7 & -3.0 & 3.5 & -1.9 \\
\hline Togo & 0.3 & -2.8 & 0.2 & -2.8 & 9.8 & -0.8 & 0.2 & -2.8 \\
\hline Uganda & 0.9 & -2.4 & 0.6 & -3.0 & 0.0 & 0.0 & 2.1 & -0.3 \\
\hline United Republic Tanzania & 0.1 & -2.3 & 0.0 & -2.5 & 1.4 & -1.0 & 0.0 & -2.4 \\
\hline Zaire & 0.3 & -2.1 & 0.1 & -2.4 & 0.0 & -0.5 & 1.3 & -1.1 \\
\hline Zambia & 0.3 & -1.7 & 0.5 & -2.9 & 0.0 & -0.6 & 1.4 & -1.4 \\
\hline Zimbabwe & 0.9 & -2.5 & 0.2 & -3.3 & 1.2 & -1.0 & 4.0 & -1.0 \\
\hline \multicolumn{9}{|l|}{ MEMO ITEM } \\
\hline Taiwan, China & 6.1 & 0.9 & 7.5 & 4.0 & 2.5 & -2.2 & 6.8 & 0.7 \\
\hline Republic of Korea & 6.0 & 0.6 & 7.8 & 4.2 & 2.7 & -2.2 & 7.1 & 0.7 \\
\hline
\end{tabular}

'Negative values show the average preferential tariff margins (in points) that the African exporter has over all other exporters of the same goods. Positive values indicate that the exporter faces a higher than average tariff due to preferences other countries receive. All tariffs shown above are the simple average (unweighted) of duties paid on the country's exports. 
iisted in Table 4 faces tariffs that are, on average, below those paid by other exporters. For some individual products these preferential tariff margins are 20 percentage points or more. This situation is markedly different from that of the Asian NICs. Taiwan (China) pays an average tariff of 7.5 percent $\mathrm{on}$ the goods it exports -- a rate that is 4.0 percentage points higher than that facing all other exporters of the same items. EEC tariffs facing Korea average 7.8 percent --4.2 points higher than that facing other exporters (many of which receive preferences) of the same goods. Again these comparisons accent the major differences these countries have toward tariff negotiations -- preference receivers would want their privileged status preserved while other countries would want to secure maximum possible reductions in MFi iffs.

Table 4 shows that African countries also receive important prefere . Jue to the GSP) in the United States and Japan, but the situation differs somewhat from thisi at: the EEC. First, the average U.S. and Japanese tariff is often higher than in Europe (i.t., an average 9.8 percent duty is paid on Togo's exports to Japan; the tariffs on Mauritius' exports to the United States average 6.4 percent) and the margins of preference are often lower. ${ }^{11}$ In several cases, the US-Canadian and US-Israel FTAs, or US Caribbean Basin Initiative (CBI) result in zero tariffs being applied to competitors' products with the result that African exporters pay a higher-than-average tariff. ${ }^{12}$ For this reason further analysis is needed to determine

\footnotetext{
"The high Japanese average is largely due to a tariff of 25 percent on Togo's exports of prepared and preserved tomatoes. The results for Mauritius are due to US tariffs of up to 35 percent on a number of textile and clothing products including men and boys shirts, babies blouses, and sweaters.

${ }^{12}$ Adverse African tariff differentials are largest for Gabon and Nigeria because US customs regulations preclude the extension of GSP tariffs to OPEC members. As a result, textile and clothing exports from these countries face a U.S. MFN duty of over 20 percent while U.S. FTA or GSP tariffs are in the range of zero to four percent. Ethiopia also had GSP treatment withdrawn due to US opposition to the government's policies.
} 
whether African countries would experience net trade gains or losses in the US and Japan.

\section{The Trade Effects of MFN Tariff Cuts}

The previous analysis showed a EEC MFN tariff liberalization would have adverse consequences for all African countries' exports due to preference erosion, and many could also experience net trade losses in the United States and Japan. This raises the key question of how large would the overall OECD displacement be, and which African countries would be most seriously affected? For answers, a trade projection model developed by the World Bank was used to simulate the effects of MFN tariff cuts (and preference erosion) on African exports. A full description of the model (named SMART -- Software for Market Analysis and Restrictions on Trade) can be found in World Bank (1992) or Erzan and Yeats (1992). ${ }^{13}$

Table 5 summarizes projections of the effects of a full removal of MFN tariffs on goods exported by African countries to the EEC, Japan and United States. ${ }^{14}$ The table

\footnotetext{
${ }^{13}$ An extensive literature exists on the empirical modelling of trade preferences. The study most often cited is Baldwin and Murray (1977). Other frequently referenced studies include Ahmad (1978), Clague (1971), Pomfret (1986) and Sapir and Baldwin (1983). The SMART model incorporates many features of the models used in these analyses. One important point to note is that none of these models account for the effects of linkages between the export sector and other supporting sectors of the economy. As such, they understate the importance of export changes on overall changes in the level of economic activity. An offsetting factor, which also is not accounted for, is that a liberaiization of OECD trade barriers should accelerate economic growth in these countries. This, in turn, would increase the demand for African exports.

${ }^{14}$ Although the precise magnitude of the Uruguay Round tariff cuts are not yet known, it is expected that they might lower existing MFN tariffs by as much as $\mathbf{5 0}$ percent. In this case, the African countries' EEC trade losses would be about one-half the figures reported in Table 5. A roughly proportional relationship exists between the depth of the eventual Uruguay Round tariff cuts and the projections for the EEC shown in the table. That is, if the Round were to liberalize tariffs by (say) 30 percent the African trade losses would be about one-third those reported. This relation does not hold for the United States and Japan where a 50 percent MFN tariff reduction might produce larger African losses than those shown in the table -- see footnote 16 for an explanation of why this occurs.
} 
ariffs on African Exports to the EEC, .

\begin{tabular}{|c|c|c|c|c|c|c|c|c|c|}
\hline \multirow[b]{3}{*}{ Exporting Country } & \multicolumn{3}{|c|}{ European Economic Community } & \multicolumn{3}{|c|}{ Japan } & \multicolumn{3}{|c|}{ United States } \\
\hline & \multirow[b]{2}{*}{$\begin{array}{r}\text { Imports } \\
(\$ 000)\end{array}$} & \multicolumn{2}{|c|}{ Projected Change } & \multirow[b]{2}{*}{$\begin{array}{r}\text { Imports } \\
(\$ 000)\end{array}$} & \multicolumn{2}{|c|}{ Projected Change } & \multirow[b]{2}{*}{$\begin{array}{r}\text { Imports } \\
(\$ 000)\end{array}$} & \multicolumn{2}{|c|}{ Projected Change } \\
\hline & & Value & Percent & & Value & Percent & & Value & Percent \\
\hline Angola & 219,927 & $-3,653$ & -1.7 & 82: & 0 & 0.0 & 67,419 & 156 & 0.2 \\
\hline Botswana & 49,079 & $-1,307$ & -2.7 & 616 & -6 & -1.0 & 17,029 & 1,712 & 10.1 \\
\hline Cameroon & 849,450 & $-16,520$ & -1.9 & 17,993 & 0 & 0.0 & 71,629 & 351 & 0.5 \\
\hline Central African Republic & 95,824 & $-1,372$ & -1.4 & 528 & 0 & 0.0 & 2,974 & -15 & -0.5 \\
\hline Chad & 51,651 & -88 & -0.2 & 4,116 & 4 & -- & 151 & 7 & 4.6 \\
\hline Congo & 208,750 & -466 & -0.2 & 17,515 & 0 & -- & 37,915 & 154 & 0.4 \\
\hline Cote d'Ivoire & $1,851,834$ & $-57,344$ & -3.1 & 20,032 & -32 & - & 243,294 & -29 & - \\
\hline Ethiopia & 167,375 & $-6,368$ & -3.8 & 57,708 & 74 & -- & 74,569 & 525 & 0.7 \\
\hline Gabon & 638,525 & $-2,414$ & -0.4 & 30,198 & $\mathbf{0}$ & 0.0 & 26,616 & 343 & 1.2 \\
\hline Ghana & 572,527 & $-3,929$ & -0.7 & 77,504 & 690 & 0.9 & 133,863 & 33 & -- \\
\hline Guinea & 285,975 & $-1,283$ & -0.4 & 1,122 & 55 & 4.9 & 160,839 & 1 & .. \\
\hline Kenya & 588,086 & $-26,354$ & -4.5 & 16,238 & 519 & 3.2 & 72,462 & 1,215 & 1.7 \\
\hline Liberia & 799,920 & -129 & -- & 32,504 & 0 & 0.0 & 114,039 & -1 & -- \\
\hline Madagascar & 191,899 & $-5,599$ & -2.9 & 42,801 & 868 & 2.0 & 39,737 & -34 & -0.1 \\
\hline Malawi & 130,268 & $-6,056$ & -4.6 & 37,227 & -1 & -- & 38,055 & 3,281 & 8.6 \\
\hline Mali & 67,460 & -254 & -0.4 & 782 & -1 & -0.1 & 7,253 & -125 & -1.7 \\
\hline Mauritania & 214,899 & $-2,743$ & -1.3 & 185,614 & $-7,505$ & -4.0 & 11,921 & -1 & -- \\
\hline Mauritius & 702,792 & $-24,539$ & -3.5 & 2,746 & 131 & 4.8 & 171,863 & 71,849 & 41.8 \\
\hline Niger & 282,886 & -619 & -0.2 & 2 & 0 & 0.0 & 2,274 & -10 & -0.4 \\
\hline Nigeria & 583,662 & $-3,657$ & -0.6 & 5,114 & 153 & 3.0 & 197,587 & 1,127 & 0.6 \\
\hline Senegal & 445,680 & $-17,625$ & -4.0 & 18,594 & 639 & 3.4 & 41,227 & -29 & -- \\
\hline Sierra Leone & 137,376 & $-1,329$ & -1.0 & 373 & 14 & 3.8 & 62,608 & 716 & 1.1 \\
\hline Sudan & 232,888 & -706 & -0.3 & 59,445 & -1 & -- & 20,629 & 36 & 0.1 \\
\hline Swaziland & 141,390 & $-3,741$ & -2.6 & 6,053 & -14 & -0.2 & 30,524 & 816 & 2.7 \\
\hline Togo & 142,732 & $-1,478$ & -1.0 & 1,431 & 7 & 0.5 & 3,395 & -8 & -0.2 \\
\hline Uganda & 235,135 & $-9,374$ & -4.0 & 9,992 & 0 & 0.0 & 43,539 & 3 & -- \\
\hline United Republic Tanzauia & 201,517 & $-5,233$ & -2.6 & 24,956 & 168 & 0.7 & 32,563 & 873 & 2.7 \\
\hline Zaire & $1,077,133$ & $-7,872$ & -0.7 & 72,007 & -242 & -0.3 & 177,455 & -57 & - \\
\hline Zambia & 336,079 & -796 & -0.2 & 391,199 & $-6,520$ & -1.7 & 24,481 & 19 & -- \\
\hline Zimbabwe & 659,153 & $-22,366$ & -3.4 & 155,472 & $-3,320$ & -2.1 & 133,049 & 5,916 & 4.4 \\
\hline ALL ABOVE COUNTRIES & $12,161,872$ & $-235,214$ & -1.9 & $1,290,704$ & $-14,320$ & -1.1 & $2,060,959$ & 88,824 & 4.3 \\
\hline \multirow{3}{*}{$\begin{array}{l}\text { MEMO ITEM } \\
\text { Taiwan, China }\end{array}$} & & & & & & & & & \\
\hline & $8,789,887$ & $2,382,770$ & 27.1 & $8,535,813$ & 392,961 & 4.6 & $25,512,280$ & $5,455,217$ & 21.3 \\
\hline & & 562 & 32.3 & $11,685,190$ & 658,820 & 5.6 & $20,559,967$ & $4,399,442$ & 21.4 \\
\hline
\end{tabular}


shows the total value of non-oil exports to each of these three markets and provides two measures of the change expected to occur under a MFN tariff liberalization. The first measure indicates the value of the projected trade change under zero MFN tariffs while the second expresses this change as a percentage of the existing export base. Negative values for these two measures indicate that the displacement of African exports would be greater than the positive trade creation effects. Once again, similar data for the Republic of Korea and Taiwan (China) are presented for comparison with the African results.

Table 5 indicates a complete EEC liberalization of MFN duties would produce annual African trade losses of over one-quarter billion dollars (note that Table 5 argues annualized figures conceal the true importance of the losses). The Côte d'Ivoire accounts for about one-fourth of the African losses ( $\$ 57$ million of this country's annual exports are displaced), with Mauritius and Kenya each recording declines of about $\$ 25$ million. ${ }^{15}$ For Kenya this implies annual export losses of about 4.5 percent -- a figure that is only surpassed by the 4.6 percent decline for Malawi. Overall, the projected EEC losses for all 30 African countries comes to about 2 percent of current trade values.

Table 5 shows that a complete liberalization of MFN tariffs would generate annual African trade losses of $\$ 14.3$ million in Japan (1.1 percent of total exports) and trade gains of

\footnotetext{
${ }^{15}$ Two tariff line products with large EEC tariff preferences account for about one-third of Côte d'Ivoire's projected trade losses. Exports of skipjack and tuna ( $\$ 82$ million) have a zero preference duty while the MFN tariff is 24 percent. On $\$ 55$ million in banana exports the spread bctween MFN and the Cote d'Ivoire preference duty is 20 percentage points.
} 
$\$ 89$ million in the United States. ${ }^{16}$ Mauritius accounts for over 80 percent of the latter total due to the relatively high U.S. MFN tariffs (in the range of 15 to 30 percent) that are applied to its textile and clothing exports. Aside from Mauritius, however, the US gains are roughly offset by export losses in Japan. Overall, the trade effects in the EEC predominate and, aside from Mauritius, African countries are projected to experience combined annual losses of $\$ 208$ million in the three OECD markets. This situation differs markedly fror that of Taiwan (China) and the Republic of Korea where trade gains of 20 percent or more are projected in the EEC and US markets. Lower export gains are estimated in Japar: -- due mainly to the erosion of some GSP preferences Japan ģives these two countries -- but the MFN tariff liberalization still increases Taiwan (China) and Korea's exports by 5 to 6 percent.

An important point to note concerning the annual projections in Table 5 is that these trade changes will occur, ceterus paribus, in each and every year after the MFN tariff cut takes place. Table 6 provides a different perspective on these projections by showing each country's annual net gains or losses in the three OECD markets combined, as well as the present

\footnotetext{
${ }^{16} \mathrm{~A}$ crucial factor influencing trade gains and loses in the United States is the depth of the MFN tariff cut, since some preferential duties are set at relatively high levels (see, for example, the statistics for Botswana and Cote d'Ivoire in Table 5). As US MFN rates are reduced down to the level of the nonzero preferential tariff, African countries will experience trade diversion. However, further reductions in MFN rates will produce trade creation (gains) that will start to offset the previous losses. This explains why, for example, a U.S. trade gain is projected for Botswana in Table 5 even though the average preferential margin on this country's exports is 1.1 percentage points. If US MFN duties were cut in half (and not completely liberalized) many of the African countries showing trade gains in Table 5 would record trade losses.
} 
Table 6. The Annual and Present Value of Projected Changes in African Countries' Exports due to a Liberalization of EEC, Japanese and US Most-Favored-Nation Tariffs.

\begin{tabular}{|c|c|c|c|c|}
\hline & \multicolumn{2}{|c|}{$\begin{array}{l}\text { Projected Change in Exports } \\
\text { to EEC, Japan and US }\end{array}$} & \multirow{2}{*}{$\begin{array}{l}\text { Total (net) } \\
\text { ODA Aid } \\
\text { Flows } \\
\text { (\$million) }\end{array}$} & \multirow{2}{*}{$\begin{array}{c}\text { Long-Term } \\
\text { Outstanding } \\
\text { Debt } \\
\text { (\$million) }\end{array}$} \\
\hline Exporting Country & $\begin{array}{l}\text { Annual Total } \\
\quad(\$ 000)\end{array}$ & $\begin{array}{l}\text { Present Value } \\
\text { (\$million) }\end{array}$ & & \\
\hline Angola & $-3,447$ & -69.9 & 87.9 & 4,670 \\
\hline Eotswana & 399 & 8.0 & 120.0 & 544 \\
\hline Cameroon & $-16,169$ & -323.4 & 300.6 & 4,186 \\
\hline Central African Republic & $-1,387$ & -27.7 & 99.3 & 653 \\
\hline Chad & -77 & -1.5 & 128.1 & 377 \\
\hline Congo & -312 & -6.2 & 79.1 & 3.218 \\
\hline Cote d'Ivoire & $-57,405$ & $-1,148.1$ & 260.1 & 12,147 \\
\hline Ethiopia & $-5,769$ & -115.4 & 377.8 & 6,860 \\
\hline Gabon & $-2,071$ & -41.5 & 121.0 & 2,482 \\
\hline Ghana & $-3,206$ & -64.1 & 350.4 & 3,346 \\
\hline Guinea & $-1,227$ & -24.5 & 191.7 & 2,054 \\
\hline Kenya & $-24,620$ & -492.4 & 620.6 & 5,652 \\
\hline Liberia & -130 & -2.6 & 38.5 & 1,425 \\
\hline Madagascar & $-4,765$ & -95.3 & 175.4 & 3,415 \\
\hline Malawi & $-2,776$ & -55.5 & 181.6 & 1,340 \\
\hline Mali & -380 & -7.6 & 300.6 & 2,187 \\
\hline Mauritania & $-10,249$ & -205.0 & 160.3 & 1,747 \\
\hline Mauritius & 47,441 & 948.8 & 50.0 & 826 \\
\hline Niger & -629 & -12.6 & 199.7 & 1,545 \\
\hline Nigeria & $-2,377$ & -47.5 & 309.8 & 27,305 \\
\hline Senegal & $-17,015$ & -351.7 & 536.3 & 3,663 \\
\hline Sierra Leone & -599 & -12.0 & 72.2 & 552 \\
\hline Sudan & -671 & -13.4 & 434.3 & 8,665 \\
\hline Swaziland & $-2,939$ & -58.8 & 11.6 & 255 \\
\hline Togo & $-1,479$ & -29.6 & 108.0 & 1,036 \\
\hline Uganda & $-9,371$ & -187.4 & 158.9 & 1,619 \\
\hline United Republic Tanzania & $-4,192$ & -83.8 & 687.6 & 4,029 \\
\hline Zaire & $-8,171$ & -163.4 & 432.9 & 7,924 \\
\hline Zambia & $-7,297$ & -145.9 & 314.2 & 4,922 \\
\hline Zimbabwe & $-19,770$ & -395.4 & 227.5 & 2,731 \\
\hline All Above Countries & $-160,710$ & $-3,225.4$ & $7,136.0$ & 121,375 \\
\hline Excluding Mauritius & $-208,151$ & $-4,174.2$ & $7,086.0$ & 120,549 \\
\hline
\end{tabular}

Source: Long-term debt and aid statistics are taken from UNCTAD, Handbook of International Trade and Development Statistics, 1991 (Tables 5.6 and 5.14). Aid disbursements include ODA flows, other official flows, and official and private export credits. 
value of the annual export changes. ${ }^{17}$ In order to put the latter figures in perspective, the table also shows each country's external debt and its recent ODA aid receipts.

Overall, the present value of the 30 African countries' combined export losses are approximately $\$ 3.2$ billion with five countries, namely, Cameroon, Côte d'Ivoire, Kenya, Senegal and Zimbabwe accounting for almost 85 percent of this total. However, the $\$ 3.2$ million loss estimate understates the impact on most countries due to the results for Mauritius where a projected trade gain of $\$ 948$ million occurs -- largely due to reduced MFN tariffs this country faces on textile and clothing exports to the United States. Excluding Mauritius, the projected losses for the 29 other African countries are $\$ 4.2$ billion -- a figure that is just under half their annual ODA assistance.

\section{Nontariff Measures Facing African Exports}

Although the previous analysis demonstrated that African exporters would experience trade losses if tariff preferences were eliminated, the possibility exists that they may still experience net gains from a general trade liberalization. Apart from tariffs, African exports may encounter nontariff measures and, in some sectors -- particularly textiles, clothing and temperate zone agriculture -- these restrictions have an important retardating effect on some developing countries' exports (see Laird and Yeats, 1991). Could the potential African trade gains from an NTM liberalization be sufficient to offset the projected losses associated with

\footnotetext{
${ }^{17}$ These present value calculations are based on a disccunt rate of 5 percent which approximates the current spread between internationally-competitive interest rates and rates of inflation in OECD countries. This figure was chosen under the assumption that the future value of increased African exports will rise in line with general rates of inflation.
} 
MFN tariff cuts?

Table 7 provides relevant information by tabulating the value of African non-fuel exports to all OECD countries and the share (percentage) of this trade subject to a nontariff measure. Similar data for the EEC, Japan and United States is also shown separately. ${ }^{18}$ As indicated, about 18 percent of the $\$ 16.8$ billion of African exports encounter nontariff measures, but there is considerable variation in this share across OECD markets and over African countries. For example, only about 10 percent of African exports to the United States encounter NTMs (implying about $\$ 163$ million in affected trade) while the corresponding trade coverage ratios for Japan and the EEC are between 22 to 23 percent.

An examination of the statistics in Table 7 shows that a relatively few countries may encounter important non-tariff measures. Almost 65 percent of Mauritius' exports encounter NTMs -- largely variable import levies on sugar and Multifiber Arrangement (MFA) quotas on textile and clothing. Mauritius is exceptional in that it (and to a much lessor extent Nigeria) is the only Sub-Saharan country whose exports are restricted by the MFA (see Table

\footnotetext{
${ }^{18}$ These tabulations utilize an inventory of nontariff trade measures maintained by the UNCTAD Secretariat in Geneva. For a description of the inventory and how it is compiled see Laird and Yeats (1991, chapter 4). One weakness of NTB coverage ratios reported in Table 7 is that they are computed using "own" trade weights. As such, products facing restrictive NTMs enter the calculation of the overall coverage ratio with relatively low (or zero) weights. Also, the inventory data (and Table 7) tell nothing about the restrictiveness or ad valorem equivalents of different NTBs (i.e., quotas, variable import levies, licensing requirements, "voluntary" export restraints, etc.), but merely indicate wheth $\epsilon_{i}$ a measure is present or not. In spite of these limitations, however, NTM inventories have been widely used in research and analysis of trade barriers. See Laird and Yeats (1989), Walter (1969)(1972), or World Bank (1993) for illustrative applications.
} 
Table 7. The Incidence of OECD Nontariff Measures on Major Sub-Saharan African C antries' Non-Fuel Exports

\begin{tabular}{|c|c|c|c|c|c|c|c|c|}
\hline \multirow[b]{2}{*}{ Exporting Country } & \multicolumn{4}{|c|}{ Value of African Exports (\$million) } & \multicolumn{4}{|c|}{ NTB Trade Coverage Ratios (\%) } \\
\hline & OECD & EEC & USA & Japan & OECD & EEC & USA & Japan \\
\hline ALL SUB-SAHARAN AFRICA & $16,836.1$ & $12,682.0$ & $1,618.2$ & $1,369.8$ & 18.1 & 22.2 & 10.1 & 23.4 \\
\hline Angola & 251.0 & 219.9 & 26.4 & 0.8 & 3.3 & 3.7 & 0.0 & 0.0 \\
\hline Botswana & na & na & na & n?. & na & $\mathbf{m a}$ & $\mathbf{n a}$ & $\mathbf{m}$ \\
\hline Cameroon & 908.6 & 894.4 & 24.7 & 18.0 & 19.6 & 20.8 & 0.0 & 0.0 \\
\hline Central African Republic & 99.3 & 94.3 & 2.6 & 0.5 & 5.0 & 5.1 & 0.0 & 0.0 \\
\hline Chad & 57.2 & 51.1 & 0.1 & 4.1 & 9.4 & 10.3 & 0.0 & 0.0 \\
\hline Congo & 237.5 & 208.7 & 5.7 & 17.5 & 42.6 & 46.5 & 0.0 & 0.0 \\
\hline Cote d'Ivoire & $2,140.6$ & $1,844.9$ & 200.4 & 20.0 & 20.6 & 21.6 & 4.4 & 17.5 \\
\hline Ethiopia & 312.2 & 167.4 & 68.5 & 57.7 & 15.9 & 26.5 & 0.0 & 0.0 \\
\hline Gabon & 714.8 & 638.5 & 20.6 & 30.2 & 54.9 & 60.8 & 0.9 & 8.9 \\
\hline Ghana & 806.4 & 570.7 & 117.2 & 77.5 & 18.8 & 10.7 & 0.0 & 88.9 \\
\hline Guinea & 443.2 & 286.0 & 132.4 & 1.1 & 1.1 & 1.3 & 0.0 & 95.2 \\
\hline Kenya & 728.8 & 588.1 & 65.6 & 16.2 & 21.7 & 23.2 & 0.2 & 26.7 \\
\hline Liberia & $1,491.9$ & 791.6 & 105.9 & 32.5 & 8.3 & 15.5 & 0.1 & 0.0 \\
\hline Madagascar & 282.4 & 191.9 & 37.4 & 42.8 & 18.3 & 12.0 & 7.9 & 58.8 \\
\hline Malawi & 223.6 & 130.3 & 30.7 & 37.2 & 14.8 & 19.4 & 13.6 & 0.0 \\
\hline Mali & 84.6 & 67.4 & 7.2 & 0.8 & 10.4 & 12.8 & 0.6 & 0.3 \\
\hline Mauritania & 402.9 & 207.0 & 10.2 & 185.6 & 47.9 & 4.5 & 0.0 & 98.8 \\
\hline Mauritius & 898.7 & 702.6 & 157.4 & 2.7 & 64.6 & 61.9 & 80.3 & 58.5 \\
\hline Niger & 300.0 & 282.9 & 4.7 & - & 4.5 & 1.1 & 6.4 & - \\
\hline Nigeria & 693.6 & 583.4 & 88.6 & 5.1 & 22.8 & 25.1 & 4.1 & 88.9 \\
\hline Senegal & 471.1 & 445.7 & 3.3 & 18.6 & 30.3 & 29.3 & 0.6 & 57.9 \\
\hline Sierra Leone & 200.7 & 137.4 & 52.6 & - & 0.8 & 0.3 & 0.0 & - \\
\hline Sudan & 322.9 & 232.9 & 19.3 & 59.4 & 18.9 & 24.6 & 0.0 & 2.3 \\
\hline Swaziland & na & na & na & $\mathbf{m a}$ & $\mathbf{m a}$ & $\mathbf{m a}$ & na & na \\
\hline Tanzania & 276.8 & 201.5 & 33.6 & 25.0 & 11.0 & 11.5 & 0.0 & 18.7 \\
\hline Togo & 191.1 & 142.7 & 1.8 & 1.4 & 7.0 & 7.3 & 3.8 & 0.1 \\
\hline Uganda & 295.1 & 235.1 & 39.8 & 10.0 & 7.6 & 7.1 & 0.0 & 0.0 \\
\hline Zaire & $1,351.5$ & $1,077.1$ & 182.8 & 72.0 & 2.5 & 3.1 & 0.0 & 0.1 \\
\hline Zambia & 774.7 & 336.1 & 23.9 & 391.2 & 1.3 & 1.9 & 0.0 & 0.1 \\
\hline Zimbabwe & 981.6 & 656.2 & 118.3 & 155.5 & 24.6 & 33.2 & 8.5 & 4.6 \\
\hline \multicolumn{9}{|l|}{ MEMO ITEM } \\
\hline All Developing Countries & $247,734.9$ & $145,254.1$ & $63,406.3$ & 26,7020 & 21.8 & 43.6 & 21.7 & 22.3 \\
\hline
\end{tabular}

Source: World Bank-UNCTAD SMART Data Base. The Sub-Saharan Africa totals include several countries not listed in the table. 
8). Gabon has an NTM coverage ratio of over 50 percent, largely due to various environmental standard certifications required on tropical timber exports, while the Congo and Mauritania have coverage ratios that exceed 40 percent. ${ }^{19}$ However, only 7 of the 29 African countries have NTM coverage ratios that exceed the "all developing country" average (see the memo item).

Are the types of nontariff measures facing African exports generally among those considered to be highly restrictive, or are they likely to be merely nuisances to trade? Table 8 provides relevant information by tabulating the OECD coverage of African exports by all NTMs and by specific types of measures (i.e., licensing requirements, MFA restrictions, other quotas and quantitative restrictions, etc.). ${ }^{20} \quad$ Although there are exceptions -- like the variable import levies on sugar from Mauritius, and MFA quotas on this country's textile and clothing exports -- Table 8 shows that most of the OECD measures facing African exports are types not thought to have important trade restrictive effects. Licensing requirements and various non-commercial regulations (largely eco-labeling requirements) predominate with the

\footnotetext{
${ }^{19}$ These certifications are required under the Washington Convention on International Trade in Species of Wild Flora and Fauna Threatened by Extinction. They must state that the exported product has been produced in accordance with established international environmental standards aimed at preservation of the species in question. See Varangis et. al. (1993) for a discussion of the rationale for, and effects or, these measures. These requirements, which almost certainly do not have a major restrictive cect on trade, largely account for the Congo's relatively high NTB coverage ratio. Mauritania's exports of fish to Japan are subject to quotas and this accounts for the OECD coverage ratio of 48 percent.

${ }^{20}$ Several points should be noted with regard to these tabulations. First, the UNCTAD inventory does not record a single instance where an African country was subject to a "voluntary" export restraint. These VERS are often among the most restrictive types of nontariff measures applied to exports (Laird and Yeats, 1991). Second, the sum of the trade coverage ratios for individual types of NTMs may exceed the combined coverage ratio for all measures. This is due to "stacking" or the multiple application of more than one nontariff measure on a single product. For example, US raw sugar imports are subject both to quotas and variable import levies.
} 
Table 8. Analysis of the Different Types of OECD Nontariff Measures Facing Sub-Saharan African Countries Non-Fuel Ėapors

\begin{tabular}{|c|c|c|c|c|c|c|c|c|}
\hline Expotting Country & $\begin{array}{c}\text { OECD Imports } \\
\text { (\$ million) }\end{array}$ & $\begin{array}{c}\text { All } \\
\text { NTMs }\end{array}$ & $\begin{array}{c}\text { Licensing } \\
\text { Requirements }\end{array}$ & $\begin{array}{c}\text { MFA and } \\
\text { Textile } \\
\text { Qur:dr }\end{array}$ & $\begin{array}{c}\text { Other } \\
\text { Quantitative } \\
\text { Restrictions }\end{array}$ & $\begin{array}{l}\text { Product } \\
\text { Specific } \\
\text { Charges }\end{array}$ & $\begin{array}{c}\text { Variable } \\
\text { Import } \\
\text { Levies }\end{array}$ & $\begin{array}{l}\text { Misc. Non- } \\
\text { Commercial } \\
\text { Measures }\end{array}$ \\
\hline ALL Sub-Saharan Africa & $16,836.1$ & 18.1 & 7.7 & 0.7 & 4.0 & 2.2 & 3.0 & 6.1 \\
\hline Angola & 251.0 & 3.3 & $\because .0$ & 0.0 & 1.2 & 0.3 & 0.0 & 1.9 \\
\hline Botswana & na & na & nia & na & na & na & na & na \\
\hline Chad & 57.2 & 9.4 & 6.0 & 0.0 & 0.0 & 0.0 & 0.0 & 3.5 \\
\hline Congo & 237.5 & 42.6 & 5.4 & 0.0 & 0.6 & 0.0 & 3.1 & 378 \\
\hline Cote d'Ivoire & $2,140.6$ & 20.6 & 1.6 & 0.0 & 11.9 & 1.7 & 1.0 & 4.8 \\
\hline Ethiopia & 312.2 & 15.9 & 2.7 & 0.0 & 1.5 & 1.6 & 0.3 & 11.9 \\
\hline Gabon & 714.8 & $54 . ?$ & 36.5 & 0.0 & 1.5 & 0.0 & 0.0 & 16.8 \\
\hline Ghana & 806.4 & 18.8 & 3.4 & 0.0 & 0.0 & 0.0 & 0.1 & 15.3 \\
\hline Mali & 84.6 & 10.4 & 2.3 & 0.0 & 0.3 & 0.3 & 0.0 & 7.7 \\
\hline Mauritania & 402.9 & 47.9 & 45.6 & 0.0 & 0.1 & 0.1 & 0.1 & 2.0 \\
\hline Mauritius & 898.7 & 64.6 & 33.4 & 13.1 & 17.0 & 0.4 & 32.5 & 1.4 \\
\hline Niger & 300.0 & 4.5 & 3.3 & 0.0 & 0.1 & 0.3 & 0.0 & 0.8 \\
\hline Nigeria & 693.6 & 22.8 & 10.8 & 0.5 & 0.5 & 0.3 & 0.1 & 11.1 \\
\hline Senegal & 471.1 & 30.3 & 3.8 & 0.0 & 13.2 & 6.1 & 0.7 & 7.1 \\
\hline Sierra Leone & 200.7 & 0.8 & 0.5 & 0.0 & 0.0 & 0.1 & 0.0 & 0.3 \\
\hline Sudan & 322.9 & 18.9 & 15.8 & 0.0 & 0.0 & 0.0 & 12.4 & 3.1 \\
\hline Swaziland & na & na & na & na & na & na & na & na \\
\hline United Republic of Tanzania & 276.8 & 11.0 & 7.1 & 0.0 & 0.9 & 0.1 & 3.2 & 2.8 \\
\hline Togo & 191.1 & 7,0 & 4.8 & 0.0 & 0.2 & 0.1 & 0.2 & 1.7 \\
\hline Uganda & 295.1 & 7.6 & 1.7 & 0.0 & 0.0 & 0.0 & 0.0 & 5.7 \\
\hline Zaire & $1,351.5$ & 2.5 & 0.1 & 0.0 & 0.0 & $0 . \iota$ & 0.0 & 2.2 \\
\hline
\end{tabular}

Note: There are no reported "voluntary" exports restraints in any OECD country involving Sub-Saharan Africa. 
trade coverage by quantitative restrictions -- measures which general do have important trade constraining effects -.. only exceeding 10 percent for three African countries, namely, Côte d'Ivoire, Mauritius and Senegal. All in all, the impression that emerges from Table 8 is that anv general removal of these measures would probably be insufficient to offset African trade losses due to erosion of OECD tariff preferences. ${ }^{21}$

\section{Summary and Conclusions}

How much are OECD trade preferences worth to Sub-Saharan Africa? The empirical evidence developed in this study suggests $\$ 4$ billion in present value terms is an appropriate estimate, and that African export losses associated with an erosion of these preferences within a Uruguay Round agreement would likely exceed any gains from liberalization of nontariff measures. These observations suggest that African countries will probably experience net trade losses as a result of Uruguay Round tariff cuts, although the magnitude of these losses cannot be projected until the depth and structure of MFN tariff cuts are finalized. African export performance has consistently been below that of other countries (see World Bank, 1992) and this performance should worsen further relative to countries like Taiwan (China) and the Republic of Korea that will experience important positive trade gains as a result of the Uruguay Round.

In order for African countries not to experience net economic losses, offsetting policies

\footnotetext{
${ }^{21}$ This conclusion is based on a detailed survey of nontariff measures' estimated ad valorem equivalents published in Laird and Yeats (1991). In most cases, licensing requirements were found to have very low nominal equivalents -- probably just one to two percent ior costs of compliance -- while Varangas et. al. (1993) indicate that eco-labeling requirements add less than $1 \mathrm{C}$ percent to the price of exports. Erzan and Svedberg (1991) come to much the same conclusion, i.e., that NTMs have only a relatively minor effect on African exports, in an independent analysis of the types of trade barriers facing African exporters.
} 
will have to be adopted. It is unlikely that any measures relating to OECD tariffs could be effectively utilized since African countries now often face zero duties in these markets (see Table 3). This precludes any attempts to restore pre-Uruguay Round preferential tariff margins. OECD countries couid, however, target those nontariff measures that are restricting African trade -- like the quotas and variable import levies or sugar -- for full and early removal. OECD countries could also increase assistance to Africa where such help is required for efficiency-increasing structural adjustment reforms.

Probably one of the most promising areas for compensatory reforms centers in the African countries' own trade regimes. Detailed statistics compiled by UNCTAD (1987) on developing countries trade barriers show that African tariffs are generally far higher than average, and that their trade regimes are often NTM-ridden. Extensive studies by the World Bank (see Thomas and Nash, 1991) document the important economic gains that can result from trade policy reform and it appears that such reform could have a major positive impact in Africa. In short, the best response to an erosion of trade preferences in foreign markets would appear to be an aggressive liberalization of African countries own trade barriers. 


\section{REFERENCES}

Ahmad, Jaleel (1978). Tokyo Rounds of Trade Negotiations and the Generalized System of Preferences, The Economic Journal, vol. 88, pp. 285-295.

Baldwin, Robert and Tracy Mu zay (1977). "MFN Tariff Reductions and Developing Country Trade Benefits Under the GSP, The Economic Journal, vol. 87, pp. 30-46.

Braga, Carlos Primo and Alexander Yeats (1992). "How Minilateral Trading Arrangements May Affect the Post-Uruguay Round World," World Bank Policy Research Working Paper, September.

Clague, Christopher (1971). "The Trade Effects of Tariff Preferences," Southern Economic Journal, vol. 38, pp. 379-389.

Erzan, Refik and Peter Svedberg (1991). "Protection Facing Exports from Sub_Saharan Africa in the EC, Japan and US," in Jonathan Frimpong-Ansah et. al. (eds.), Trade and Development in Sub-Saharan Africa, (Manchester: Manchester University Press).

Erzan, Refik and Alexander Yeats (1992). "Free Trade Agreements with the United States -- What's in it for Latin America," World Bank Policy Research Working Paper Number 827, (Washington: World Bank).

Laird, Samuel and Alexander Yeats (1987). "Tariff Cutting Formulas and Complications," in J. Michael Finger and Andrzej Olechowski (eds.), The Uruguay Round: A Handbook for the Multilateral Trade Negotiations, (Washington: World Bank)

Laird, Samuel and Alexander Yeats (1989). " Nontariff Barriers of Developed Countries, 1966-1986," Finance and Development, vol. 26, no. 1, (March).

Laird, Samuel and Alexander Yeats (1991). Quantitative Methods for Trade Barrier Analysis, (London: Macmillan Press).

Pomfret, Richard (1986). "The Effects of Trade Preferences for Developing Countries," Southern Economic Journal, vol. 53, pp. 18-26.

Sapir, Andre and Robert Baldwin (1983). "India and the Tokyo Round, World Development, vol. 11, pp. 565-574. 
Schott, Jeffrey (1989). More Free Trade Areas? (Washington: Institute for International Economics, May).

Thomas, Vinod and John Nash (1991). Best Practices in Trade Policy Reform, (Oxford: Oxford University Press for the World Bank).

UNCTAD (1982). Assessment of the Results of the Multilateral Trade Negotiations, (TD/B/778/Rev. 1), (New York: United Nations).

UNCT 4D (1987). Handbook of Trade Control Measures of Developing Countries: A Statistical Analysis of Trade Control Measures of Developing Countries 1987, (UNCTAD/DDM/Misc 2), (Geneva: UNCTAD).

Varangis, Panayotis, Carlos A. Primo Braga and Kenji Takeuchi (1993). "Tropical Timber Trade Policies: What Impact will Eco-Labeing Have?," World Bank Policy Research Working Paper No. 1156, (Washington: World Bank, July).

Walter, Ingo (1969). "Nontariff Barriers and the Free-Trade Area Option," Banca Nazionale del Lavoro Quarterly Review, vol. 22 (March)

Walter, Ingo (1972). "Nontariff Protection Among Industrial Countries: Some Preliminary Empirical Evidence," Economia Internazionale, vol. 25, (May).

World Bank (1992). Global Economic Prospects and the Developing Countries, 1992, (Washington: World Bank, April).

World Bank (1993). Global Economic Prospects and the Developing Countries, 1993, (Washington: World Bank, April).

Yeats, Alexander (1987). "The Escalation of Trade Barriers, " in J. Michael Finger and Andrzej Olechowski (eds.), The Uruguay Round: A Handbook for the Multilateral Trade Negotiations, (Washington: World Bank).

Yeats, Alexander (1990). "On the Accuracy of Economic Observations: Do Sub-Saharan Trade Statistics Mean Anything?," The World Bank Economic Review, Volume 4, No. 2, May.

Yeats, Alexander (1992). "Can a Manufactured Good Cease to be a Manufactured Good Merely by Crossing a National Frontier?", Bulletin of Economic Research, vol. 44, no. 3, (July). 


\section{Policy Research Working Paper Series}

Title

WPS1235 Eastern Europe's Experience with Banking Reform: is There a Role for Banks in the Transition?

WPS1236 The Impact of Two-Tier Producer and Consumer Food Pricing in India

WPS1237 Bank Performance and the Impact of Finallcial Restructuring in a Macroeconomic Framework: A New Application

WPS1238 Kenya: Structural Adjustment in the 1980 s

WPS1239 Principles of Regulatory Policy Design

WPS1240 Financing the Storm: Macroeconomic Crisis in Russia, 1992-93

WPS1241 Regulation, Institutions, and Commitment in the British Telecommunications Sector

WPS1242 Financial Policies in Socialist Countries in Transition

Boris Pleskovic

Punam Chuhan

WPS1243 Are Institutional Investors an Important Source of Portfolio Investment in Emerging Markets?

WPS1244 Difficulties of Transferring RiskBased Capital Requirements to Developing Countries

WPS1245 The Adding-Up Problem: Strategies for Primary Commodity Exports in Sub-Saharan Africa

WPS1246 Determinants of Cross-Country Income Inequality: An "Augmented" Kuznets' Hypothesis

WPS1247 Complex Transactions Under Uncertainty: Brazil's Machine Tool Industry

Takamasa Akiyama

Donald F. Larson

Branko Milanovic

Brian Aitken

WPS1248 Do Domestic Firms Benefit from Foreign Direct Investment? Evidence from Panel Data
January 1994

January 1994

Contact

for paper

December 1993

N. Jose

33688

December 1993

S. Fallon 38009

December 1993

C. Lim 30864

January 1994

V. Saldanha 35742

WDR

31393

January 1994

R. Martin

39026

January 1994

B. Moore 35261

January 1994

M. Jandu

33103

January 1994

R. Vo

31047

January 1994

P. Sintim-Aboagye 38526

January 1994

A. Kim

33715

R. Martin 39065

P. Sintim-Aboagye 37644

February 1994

D. Bailantyne 37947 


\section{Policy Research Working Paper Series}

Title

\author{
WPS1249 Competitiveness and Environmental Piritta Sorsa \\ Standards: Some Exploratory Results \\ WPS1250 Explaining Miracles: Growth \\ Regressions Meet the Gang of F Jur \\ WPS1251 Excise Taxes \\ John F. Due \\ WPS1252 On the Dangers of Decentralization \\ WPS1253 Can Competition Policy Control $301 ?$ \\ J. Michael Finger \\ K. C. Fung \\ Rémiy Prud'homme
}

WPS1254 What Are OECD Trade Preferences Worth to Sub-Saharan Africa?
Contact

Date

for paper

February 1994

P. Kokila 33716

February 1994

R. Martin 39026

February 1994

C. Jones 37699

February 1994

TWTD 31005

February 1994

M. Patena 37947

February 1994 J. Jacobson 33710 